\title{
Rethinking \& Recasting Bilateral Investment Treaties as Integrative Tools for Sustainable Development: The Kenyan Experience
}

\author{
Faith Simiyu $^{1}$
}

\begin{abstract}
Sustainable development is a fundamental principle of International Law. It is closely related to and [should be] a core objective of any international treaty seeking to address developmental concerns. Curiously, however, a critical review of [legal] literature reveals seemingly little attention given to the actual assessment of 'how and to what extent' existing Bilateral Investment Treaties (BITs) have integrated sustainable developmental concerns. This is particularly in relation to BITs involving developing countries in Africa such as Kenya. Accordingly, taking Kenya as an illustrative case, this study makes a critical assessment of the BITs concluded between Kenya, the Netherlands, Britain, and Germany; with a view to establishing how and to what extent the said BITs have integrated sustainable development. The study argues that most (if not all) BITs remain silent on sustainable development. Further, the methods of integrating sustainable development are premised on placing host state obligations to protect investors and their investments. In doing so, the implied assumption is that protection will attract foreign investment necessary for financing sustainable development. Nevertheless, as the paper highlights, difficulties have arisen in measuring how revenue generated from foreign investment has contributed to the sustainable development due to the unpredictable patterns of revenue inflow from foreign. This in turn creates difficulties in using the said revenue when planning for long-term sustainable yields in development. Accordingly, the paper urges a collectively rethinking of the usage of BITs as a tool for sustainable development involving, states taking deliberate steps to recast BITs to ensure that the process of negotiation of BITs, the structure that emanates from the negotiation and the implementation of the BITs; explicitly seek to integrate sustainable development. This necessarily involves placing obligations on both state and non-state actors in realizing sustainable development.
\end{abstract}

Key words: Sustainable Development, Foreign Investments, public benefit.

\subsection{Introduction}

Sustainable development has received worldwide recognition and acceptance as a fundamental framework of action to be taken internationally and nationally by governments, international organizations, and business enterprises in the pursuit of developmental concerns. ${ }^{1}$ Gradually, sustainable development has now been embraced

${ }^{1}$ Segger, C, M., Gehring, M, W., \& Newcombe, A. (Eds.). (2011). Sustainable Development in World Investment Law. The Netherlands: Kluwer Law International pg 4-9.

*Assistant Lecturer, School of Law, Jomo Kenyatta University of Agriculture and Technology, 
not only as a common concern ${ }^{2}$ to both the developed and developing world; but also a global objective and commitment. ${ }^{3}$ Equally, there is consensus that International Law (including International Investment Law through Bilateral Investment Treaties (BITs)) is pivotal in achieving sustainable development. ${ }^{4}$ This acknowledgement has largely informed a number of initiatives already undertaken or being undertaken to make sustainable development an explicit objective of various treaties including BITs. As Gehring and Newcombe have observed, more than fifty binding international treaties have sought to integrate, in one form or another, sustainable development as an explicit objective. $^{5}$

The first BIT was concluded between Germany and Pakistan in 1959. In subsequent years, the period between the 1960's to 1970's witnessed the conclusion of several BITs between developed and developing countries. Of peculiarity is the fact that the BITs exclusively addressed the protection of investment. ${ }^{6}$ The assumption was that through according higher levels of protections to foreign investment, host states would be able to attract and reap the economic benefits of foreign investment. By the early-1980's, a certain trend emerged:- when concluding BITs, developing countries sought to create a stable, transparent, and predictable climate for the conduit of investment activities through according higher levels of protection to foreign investors. Thus, the substantive provisions of BITs were largely tailored towards protecting investors through minimum standards of treatment clauses that included: fair and equitable treatment of investment in accordance to customary international law, the guarantee of full protection and security of investment, Most-favoured Nation treatment and the guarantee of compensation in case of expropriation. These minimum standards of treatment established the traditional role of BITS as legally binding instruments for protecting foreign investment.

From the 1980's, however, changing economic and political realities challenged the traditional role of BITs; as legally binding instruments for protecting foreign investment. The changes precipitated the need to rethink the traditional scope of BITs as protectors of investment, to address development generally and sustainable development in particular. Amongst the important political and economic changes of this period was the process of decolonization and the sovereign debt crisis of the mid- 1980's. On one hand, the process of decolonization saw the removal of economic dominance in developing countries hence developing counties wanted to assert their rights as 'sovereign' states in regulating foreign investment to induce development. On a different note, the sovereign debt crisis of the mid-1980's triggered the unwillingness of commercial banks to provide lending facilities in the form of official capital flow, to developing countries. In turn, this necessitated the search for alternative sources of capital in the form of foreign

\footnotetext{
2 Gro H, Brundtland et al. 1987. Our Common Future: The Report of the World Commission on Environment and Development. Oxford: Oxford University Press

${ }^{3}$ Separate Opinion by H.E. Judge Weeramantry, Case Concerning Gabcikovo-Nagymaros Project (Hungary v. Slovakia), and [1997] I.C.J. Rep. 95.

${ }^{4}$ International Law Association. (2004). First Report of the International Law Committee on International Law on Sustainable Development. London: International Law Association at pg. 3. See also Principle 27, Rio Declaration on Environment and Development, Agenda 21: Programme of Action for Sustainable Development, Report of the UNCED 1992, vol. U.N. GAOR, $46^{\text {th }}$ Sess., and Agenda Item 21at Chapter 39.

${ }^{5}$ Ibid at $n 1$ page 5

${ }^{6}$ Newcombe, A \& Luis, P. (2009). Law and Practice of Investment Treaties: Standards of Treatment. The Netherlands: Kluwer Law International.
} 
investment. ${ }^{7}$ As a result, developing countries pursued programs aimed at liberalizing and protecting investment as a means of attracting and reaping the associated developmental benefits of investment through BITs. ${ }^{8}$

By the end of the 1990's foreign investment was widely regarded as 'part of the solution' to advancing development. ${ }^{9}$ Therefore, two key assumptions have and still guide the usage of BITs as tools for addressing development generally and sustainable development in particular. First is that foreign investment, especially Foreign Direct Investment (FDI), provides a viable source of capital or revenue for financing sustainable development. Secondly, foreign investment should be promoted (or encouraged), and protected through appropriate national and international regulatory frameworks under BITs; in order to induce the positive developmental benefits. ${ }^{10}$ These assumptions have in turn informed the methods by which BITs integrate sustainable development. ${ }^{11}$ Nevertheless, as this paper highlights, difficulties have arisen in correlating how revenue generated from foreign investment has contributed to sustainable development due to unpredictable patterns of FDI inflow. In turn, it becomes difficult to utilize revenue from foreign investment in planning development projects that yield long-term sustainable benefits. Curiously, however, there has been seemingly been little attention given to the actual analysis of how and the extent to which existing BITs have integrated sustainable development. This is particularly so in relation to BITs involving developing countries such as Kenya. Accordingly, taking Kenya as an illustrative case, this paper makes a critical assessment of the extent to which the BITS it has concluded with Germany, Britain and the Netherlands have integrated sustainable development.The substantive provisions of the said BITs are audited, findings tabulated and assessed.

The paper begins by conceptualizing sustainable development in two ways. Firstly, as a concept merging from policy documents that echo sustainable development pillars and secondly, as an umbrella term in the field of International law relating to sustainable development where specific international law principles relating to sustainable development have been enacted. In doing so, emphasis is given to the principle of integration that calls for a systemic approach of integrating sustainable development within and between treaty regimes such as BITs. Based on this, the paper then extracts the indicators of integration of sustainable development and conducts an assessment on how and to what extent the Kenyan BITs have integrated sustainable development.

\subsection{Conceptualizing Sustainable Development}

The meaning, purposes, content and legal status of sustainable development remains uncertain, complex and highly contested. ${ }^{12}$ Indeed, the process of conceptualizing sustainable development has evolved over time in terms of not only meaning and object, but also the constituency of interest groups. With regard to

7 Pritchard, R. (1996).Economic Development, Foreign Investment and the Law: Issues of Private Sector Involvement, Foreign Investment, and Rule of Law in a new Era. The Hague London and Boston: Kluwer Law International and International bar Association.

${ }^{8}$ CFIUS, Annual Report to Congress, Report Period CY2010 (Washington, DC: CFIUS, 2011).

9 Savant, K. (2012). The times they are a-changing'-again-in the relationships between governments and multinational enterprises: From control, to liberalization to rebalancing. Canada: Vale Columbia Center on Sustainable International Investment.

${ }^{10} \mathrm{Ibid} \mathrm{n} 7$.

${ }^{11}$ World Development Movement \& Friends of the Earth. (2011). Investment and the WTO: Bursting the Myths. London: World Development Movement and Friends of the Earth.

${ }^{12}$ IpsaDubava 
meaning, sustainable development has tended to be viewed and defined from four major perspectives, namely: sustainable development as an expression of community interests; sustainable development as a concept emerging from policy goals; sustainable development as core element of the principle of integration; sustainable development as underpinned by specificInternational Law principles relating sustainable development. ${ }^{13}$ Implicit in these perspectives is the interplay between development and the interests of different players (investors, host state, public) on the one hand, and international institutions or instruments on the other. This paper conceptualizes sustainable development from policy documents that attempt to provide its meaning and with reference to international law principles relating to sustainable development seek to further the development of International law(including International Investment Law through BITs) relating to sustainable development. ${ }^{14}$

\subsection{Meaning of Sustainable Development}

There are various definitions of sustainable development. However, two definitions are significant. First is the most popular, accepted and commonly cited definition of sustainable development as provided in the Brundtland report, namely;

Sustainable development is development that meets the needs of the present without compromising the ability of future generations to meet their own needs. ${ }^{15}$

Second is the definition given by the International Law Association (ILA), which states that:

Sustainable development [is] a comprehensive and integrated approach to economic, social and political processes[aimed] at the sustainable use of natural resources of the earth and the protection of the environment on which nature and human life as well as social and economic development depend, and which seeks to realize the right of human beings to an adequate living standard on the basis of their active, free, meaningful participation in development and in the fair distribution of benefits resulting there from, with due regard to the needs and interests of future generations... emphasis added ${ }^{16}$

Notably, the Brundtland report primes development, acknowledges inherent limitations of the environment and roots for inter and intra-generational equity. ${ }^{17}$ More importantly, by laying emphasis on 'needs', it introduces the developmental concerns that must be addressed in the quest for sustainability which are 'essential needs of the world's poor, to which overriding priority should be given'.18

On the other hand, the definition by the International Law Association (ILA), adopted in this paper, conceptualizes sustainable development as being anchored on the integration and/or convergence between and among economic, social, and environmental

${ }^{13}$ Dubava, I. 2010. Reconciling International Investment Law and Sustainable Development: Necessity or Luxury? Society of International Economic Law \& University of Missouri Kansas City School of law. Study presented at the Second Biennial Conference held 8-10 July 2010 at the University of Barcelona. Available onlinehttp://www.ssrn.com/link/SIEL-2010-Barcelona-Conference.html

${ }^{14}$ See Principle 27 of the Rio Declaration

${ }^{15}$ Brundtland report op Cit $\mathrm{n} 2$ at page 8, 46.

${ }^{16}$ International Law Association. (2002). New Delhi Declaration on the Principles of International Law Related to Sustainable Development. London: International Law Association

${ }^{17}$ Brundtland Report supra n 2 at Chapter 2. See also Drexhage, J, J., \& Murphy, and D. (2010). Sustainable Development: From Brundtland to Rio 2012.Background Study Report prepared for consideration by the High Level Panel on Global Sustainability at its first meeting, 19 September 2010. New York: United Nations

${ }^{18}$ See Brundtland Report , pp.8,46 
imperatives that constitute the pillars of sustainable development. On one hand, the environmental pillar of sustainable development calls for environmental protection and is acknowledged as the definitive part of 'sustainability' since what is to be 'sustained' can be classified either as nature, life support systems or the community. ${ }^{19}$ On the other hand, economic development as a pillar of sustainable development is considered the 'needs' part of sustainable development specifically, the meeting of 'economic needs' in terms of quantity such as economic growth or an increase in the average annual income per person (GNP per capita) orin terms of quality such as improvements in material welfare of low income countries, poverty and disease eradication, improved standards of living etc. ${ }^{20}$ Related, the social pillar introduces a human rights approach to development that requires the removal of major sources of 'unfreedom'such as poverty, tyranny, poor economic opportunities, systematic social deprivation or lack of equity, neglect of public facilities, as well as repressive and intolerant states. ${ }^{21}$ In this regard, the social pillar calls for a guarantee of human rights and freedom and has therefore been coined as the social (human rights) pillar of sustainable development. These pillars will be used in this paper to identify the principles of international law that govern the same.

\subsection{International Law Principles Relating to Sustainable Development}

The International Law principles on sustainable development emerged from several conferences that adopted, fortified and enacted policy documents echoing sustainable development principles. ${ }^{22}$ Of particular importance to this paper is the $70^{\text {th }}$ ILA Conference of the International Law Association (ILA) held in New Delhi in 2002. The ILA conference saw the enactment of the 'New Delhi declaration on International Law principles relating to sustainable development' (ILA Declaration). The ILA Declaration contains seven (7) International Law principles on sustainable development namely:(i) the principle of integration and inter-relationship; (ii) the principle of common but differentiated responsibilities, (iii) the 'precautionary principle'; (iv) the principle of good governance; $(\mathrm{v})$ the principle of public participation; (v) the principle of equity and poverty eradication; (vi) the principle duty of states to ensure sustainable use of natural resources.Below we examine five (5) of the principles with emphasis given to the principle of integration as it forms the starting point of scope of this paper.

\subsection{The Principle of Integration}

The principle of integration is the backbone of the concept sustainable development and the most operationally significant principle ${ }^{23}$. Indeed, various international tribunals and instruments echo the centrality of the integration principleto achieving a

\footnotetext{
${ }^{19}$ Kates, W, R.; Parris, M, Thomas \& Leiserowitz, A. Anthony. (2005). What is Sustainable Development? Goals, Indicators, Values, and Practice. Washington: United States.

${ }^{20}$ Hardwick, Bahadur.; \& Langmead. (1999). An Introduction to Modern Economics (5 ${ }^{\text {th }}$ Ed.). United Kingdom: Longman Publishers pg 7

${ }^{21}$ Sen, A, K. (1999). Development as Freedom. United Kingdom: Oxford University Press

${ }^{22} \mathrm{Key}$ among the conferences referred to above, which saw declarations and the enactment of various documents echoing the sustainable development principles and plans of implementation were held under the auspices of the United Nation (UN). These conferences include: i) the United Nations Conference on Human Environment held at Stockholm held in 1972; ii) the United Nation Conference on Environment and Development held at Rio de Janeiro in 1992; iii) the Johannesburg World Summit on Sustainable Development of 2002 and; iv)the $70^{\text {th }}$ Conference of the International Law Association(ILA) held in New Delhi in 2002.

${ }^{23}$ ILA first report ibid n 6 at pg 4
} 
balance amongst the three pillars of sustainable development. For instance, the Shrimp Turtle case ${ }^{24}$ and Iron Rhine Award ${ }^{25}$ re-emphasized that environmental protection and development cannot be considered in isolation since they mutually reinforce and integrate with each other. Similarly, Judge Weeramantry in the Gabcikovo-Nagymaros Project case reiterated the need to reconcile the development concerns with environmental protection since the two cannot stand-alone. ${ }^{26}$ Likewise, the Rio Declaration echoes the fact in order to achieve sustainable development, environmental protection is an integral part of the developmental process and cannot be considered in isolation. ${ }^{27}$

The most comprehensive explanation on the principle of integration is encapsulated in Article 7.1 of the ILA Declaration which states that the principle of integration is reflective of:

The inter-dependence of the socio-economic, environmental and human rightsaspects of the principles and rules of international law relating to sustainable development as well as the interdependence of the needs of the current and future generations of humankind...emphasis added

The immediate provision indicates that the integration principle, as a core element of sustainable development, takes cognizance of the fact that sustainable development is interconnected to social (human rights), environmental or economic development aspects. Arguably, these legal aspects determine under which pillar a given International Law principle relating tosustainable development may fall. In turn, they are the aspects that will be used by the paper to indicate the extent to which sustainable development has been integrated into BITs. For instance, as we shall show, if a principle contains legal aspects that seek to promote environmental protection; we classify the principle as falling under the environmental pillar of sustainable development.

According to Article 7.3 and 7.4 of the ILA declaration, two conditions must be fulfilled in order to successfully implement the integration principle. Firstly, the removal of conflicts between competing economic, social and environmental considerations and secondly; taking cognizance of the interrelatedness of the various International Law principles relating to sustainable development. Taken together, these two conditions call for an integrative approach in the realization of and balance between the three-pillars of sustainable development and their related principles. Thus, three integrative approaches to sustainable development have been introduced by the ILA Toronto Committee 2006. These are: (i)the systemic approach which involves the integration of sustainable development considerations within and between treaty regimes;(ii) the institutional approach which involves changes in the national, regional and international institutional practices on sustainable development and; (iii)the legal approach which involves judicial reasoning taking into cognizance the interrelationship between sustainable development and various norms. ${ }^{28}$ Hence, based on the systemic approach, the next section briefly examines the legal aspects of four international law principles on sustainable

24 US-Shrimps, AB Report, United States-Import Prohibition of Certain Shrimp and ShrimpProducts,WT/DS58/AB/R,6 November 1998,DSR 1998:VII,2755 2005 at Para 59

${ }^{25}$ Iron Rhine Railway, The Kingdom of Belgium vs. The Kingdom of the Netherlands,PCA,Award 24 May

26 United States -Import Prohibition of Certain Shrimp and Shrimp Products (WT/DS58/AB/R), 12 October 119 Para 153. See also Handl, G. 'Sustainable Development: General Rules versus Specific Obligations', in Sustainable Development and International Law (edn W. Lang, 1995)

${ }^{27}$ See Principle 4 of the Rio Declaration on Environment and Development, 1992

${ }^{28}$ ILA Report of the Seventy-Second Conference(Held in Toronto, 4-8 June 2006) 
development and derives how some their legal aspects act as indicators of incorporating or integration of sustainable development in the Kenyan BITs.

\subsubsection{The Principle Of Precautionary Approach To Human Health, Natural Resources And Eco-Systems}

The precautionary principle commits all states and non-state actors to avoid human activities that may cause significant harm to human health, natural resources and eco-systems. ${ }^{29}$ The precautionary principle requires action to prevent environmental damage be taken even 'before scientific proof of harm is provided'. ${ }^{0}$ To achieve this, two main activities are envisaged namely; i) accountability for environmental harm and ii) Environmental Impact Assessment (EIA) before carrying out a project at a natural site. Therefore, by integrating this principle into BITs, one will be mitigating potential environment harm that may affect a people's right to a clean and healthy environment. Given the focus on the environment, this principle falls under the environmental protection pillar of sustainable development, for assessment purposes.

\subsubsection{The Duty Of States To Ensure Sustainable Use Of Natural Resources}

The 'sovereign right' of states over the natural resources has informed this principle. States have the responsibility to ensure that the activities within their jurisdiction do not cause environmental damage to other states. Further, due regard is given to the conservation and sustainable use of natural resources. ${ }^{31}$ Certainly, the environment is of particular concern in this principle and therefore this principle falls under the environmental protection pillar of sustainable development.

\subsubsection{The Principle Of Equity and Poverty Eradication}

This principle essentially commits states to ensure both inter-generational and intra-generational equity and the eradication of poverty. On one hand, 'intra and intergenerational equity' is indicated by fair access to natural resources by peoples of the current and future generations. ${ }^{32}$ On the other hand, 'poverty eradication' is indicated by a commitment to improving the standards of living for all peoples. ${ }^{33}$ This requires measures being taken to ensure that the nation and its people are economically empowered in terms of raising their standards of living. Collectively, it can be argued equity and poverty eradication seeks to meet the economic 'needs' of mankind for prosperity and posterity. Therefore, both principles fall under the economic pillar of sustainable development.

\subsubsection{The Principle of Public Participation}

This principle calls upon public participation or involvement in all levels of decision-making at the national or international level. The public in this context includes women, youth, and civil societies. Amongst the specific requirements of this principle is the protection of the human rights to hold and express opinion as well as the right to

\footnotetext{
${ }^{29}$ See Article 4.1 of ILA Declaration

30 Howley, J. (2009). The Gabcikovo-Nagymaros Case: The Influence of the International Cour of Justice on the Law of Sustainable Development. Queensland Law Student Review Volume 2 number1.

31 Articles 1.1 and 1.2 of ILA Declaration

${ }^{32}$ Article 2.1 and 2.2 of the ILA declaration

${ }^{33}$ Principle 5 of the Rio Declaration
} 
access judicial or administrative procedures. ${ }^{34}$ Arguably, given the focus on the 'people' as social beings, this principle thereforefalls within the social (human rights) pillar of sustainable development.Table 1 below provides a summary of the preceding principles and how they are to be used as indicators of integration of the pillars of sustainable development.

\begin{tabular}{|c|c|c|}
\hline Pillar & Principle & Indicators of Integration of Sustainable Development \\
\hline \multirow[t]{2}{*}{ Environment } & $\begin{array}{l}\text { Precautionary } \\
\text { Principle }\end{array}$ & $\begin{array}{l}\text { - Commits parties to avoid human activities that may cause } \\
\text { significant harm to human health, natural resources or the eco-system } \\
\text { - } \quad \text { Integrates accountability of environmental harm } \\
\text { - } \quad \text { Prioritizes environmental impact assessment }\end{array}$ \\
\hline & $\begin{array}{l}\text { State } \\
\text { responsibility } \\
\text { for ensuring } \\
\text { sustainable } \\
\text { use of natural } \\
\text { resources }\end{array}$ & $\begin{array}{l}\text { - Recognizes and upholds(affirms) rights and responsibilities } \\
\text { pursuant to a host states own environmental and developmental policies } \\
\text { - } \\
\text { Promotion of waste minimization policies } \\
\text { and beyond borders }\end{array}$ \\
\hline \multirow[t]{2}{*}{$\begin{array}{l}\text { Economic } \\
\text { Development }\end{array}$} & $\begin{array}{l}\text { Poverty } \\
\text { Eradication }\end{array}$ & $\begin{array}{l}\text { - Encourages co-operation for the eradication of poverty in a } \\
\text { manner that improves the living standards of all people for prosperity and } \\
\text { posterity }\end{array}$ \\
\hline & Equity & $\begin{array}{l}\text { Guarantees, promotes or provides inter- and intra- generational } \\
\text { equity in terms of fair access to natural resources }\end{array}$ \\
\hline $\begin{array}{l}\text { Social } \\
\text { Development }\end{array}$ & $\begin{array}{l}\text { Public } \\
\text { Participation }\end{array}$ & $\begin{array}{l}\text { - Guarantees the right to access judicial organs and business } \\
\text { information } \\
\text { - } \quad \text { Uphold the rights to express opinions and access information } \\
\text { - } \quad \text { Considers the participation of the public in development }\end{array}$ \\
\hline
\end{tabular}

Source: Author

\section{Bilateral Investment Treaties as Integrative Tools for Sustainable Development in Kenya}

In accordance with the pillars and indicators of integration of sustainable development identified in the preceding sections, we conducted a critical assessment of how the Kenyan BITs have integrated sustainable development. The BITs that are assessed comprise of (i) the Agreement for Economic Co-operation between the Government of the Kingdom of the Netherlands and the Government of the Republic of Kenya (hereafter referred to as the Netherlands-Kenya BIT); (ii) the Treaty between the Federal Republic of Germany and the Republic of Kenya (hereafter referred to as the German-Kenya BIT) and; (iii) the Agreement between the Government of the United Kingdom of Great Britain and Northern Ireland and the Government of the Republic of Kenya (hereafter referred to as the UK-Kenya BIT). The assessments unearthed three methods by the Kenyan BITs impliedly or explicitly integrate sustainable development.

${ }^{34}$ Article 5.3 ILA Declaration 
These are by way of preambular declarations, specific declaratory clauses, and general exception clauses. ${ }^{35}$

Table 2 below provides a summary of the findings and is followed by a critical assessment of the extent of integration of sustainable development in the Kenyan BITs.

Table 2: Analysis of BITs and Extent of Integration of Principles of Sustainable Development

\begin{tabular}{|c|c|c|c|c|c|c|}
\hline \multirow[t]{3}{*}{ BIT } & \multirow{3}{*}{$\begin{array}{l}\text { BIT } \\
\text { Structure }\end{array}$} & \multicolumn{5}{|c|}{ Principle of Sustainable Development } \\
\hline & & \multicolumn{2}{|c|}{ Environmental protection } & \multicolumn{2}{|c|}{ Economic Dev. } & \multirow{2}{*}{$\begin{array}{l}\text { Social Dev. } \\
\text { Public } \\
\text { Participation }\end{array}$} \\
\hline & & $\begin{array}{l}\text { Precautionary } \\
\text { Approach to } \\
\text { human health, } \\
\text { natural } \\
\text { resources and } \\
\text { eco-systems }\end{array}$ & $\begin{array}{l}\text { State } \\
\text { responsibility } \\
\text { for ensuring } \\
\text { sustainable use } \\
\text { of natural } \\
\text { resources }\end{array}$ & $\begin{array}{l}\text { Poverty } \\
\text { Eradication }\end{array}$ & Equity & \\
\hline \multirow{3}{*}{$\begin{array}{l}\text { Netherland } \\
\text { s-Kenya } \\
\text { BIT }\end{array}$} & Preamble & $\mathrm{X}$ & $\mathrm{X}$ & $\checkmark$ & $\checkmark$ & $\mathrm{X}$ \\
\hline & $\begin{array}{l}\text { Specific } \\
\text { declarations }\end{array}$ & $\mathrm{X}$ & $\mathrm{X}$ & $\mathrm{X}$ & $\mathrm{X}$ & $\mathrm{X}$ \\
\hline & $\begin{array}{l}\text { General } \\
\text { exceptions }\end{array}$ & $\mathrm{X}$ & $\mathrm{X}$ & $\mathrm{X}$ & $\mathrm{X}$ & $\checkmark$ \\
\hline \multirow{3}{*}{$\begin{array}{l}\text { German- } \\
\text { Kenya BIT }\end{array}$} & Preamble & $\mathrm{X}$ & $\mathrm{X}$ & $\checkmark$ & $\checkmark$ & $\mathrm{X}$ \\
\hline & $\begin{array}{l}\text { Specific } \\
\text { declarations }\end{array}$ & $\mathrm{X}$ & $\mathrm{X}$ & $\mathrm{X}$ & $\mathrm{X}$ & $\mathrm{X}$ \\
\hline & $\begin{array}{l}\text { General } \\
\text { exceptions }\end{array}$ & $\mathrm{X}$ & $\mathrm{X}$ & $\mathrm{X}$ & $\mathrm{X}$ & $\checkmark$ \\
\hline \multirow{3}{*}{$\begin{array}{l}\text { UK-Kenya } \\
\text { BIT }\end{array}$} & Preamble & $\mathrm{X}$ & $\mathrm{X}$ & $\checkmark$ & $\checkmark$ & $\mathrm{X}$ \\
\hline & $\begin{array}{l}\text { Specific } \\
\text { declarations }\end{array}$ & $\mathrm{X}$ & $\mathrm{X}$ & $\mathrm{X}$ & $\mathrm{X}$ & $\mathrm{X}$ \\
\hline & $\begin{array}{l}\text { General } \\
\text { exceptions }\end{array}$ & $\mathrm{X}$ & $\mathrm{X}$ & $\mathrm{X}$ & $\mathrm{X}$ & $\checkmark$ \\
\hline
\end{tabular}

Source: Author $\underline{\text { KEY }}$

$\checkmark \quad$ Implies that the stated principle of Sustainable Development has been integrated

$\mathrm{X} \quad$ Implies the stated principle of Sustainable Development has not been integrated

\subsection{Assessment of the Extent of Integration of Sustainable Development by Kenyan BITs}

\subsubsection{BITs and the Environmental Protection Pillar}

It is evident from table 2 that as far as the environmental protection pillar is concerned, none of the BITs explicitly integrateenvironmental protection either as a preambular declaration, specific declaration or as a general exception. As discussed, environmental protection as a pillar of sustainable development is underpinned by two key principles, namely: precautionary approach and state responsibility for ensuring sustainable use of natural resources. None of these principles are explicitlyintegrated into the three BITs. In retrospect, one provision of the Netherlands-Kenya BIT could be said to imply efforts towards integrating the environmental pillar of sustainable development. Article 3 of the Netherlands -Kenya BITexplicitly provides that:

${ }^{35}$ UNCTAD. (2004). Key Terms and Concepts in IIAs: A Glossary. Series on Issues in International Investment Agreements. United Nations: New York and Geneva 
The Contracting Parties shall facilitate the intensification of commercial relations between their respective countries. They shall, within the framework of and subject to their national legislation, further the co-operation ....in order to develop their national resources...emphasis added

The immediate article infers some level of sensitivity to the environment by the contracting states where each needs to develop national resources. Impliedly, sincethe environment consists of nature and life support systems, national resources may include the environment which can be developed or exploited to cater for environmental needs. However, in the literal sense, because Article 3 refers to the notion "national" resources instead of 'natural' resources or 'sustainable utilization of the natural resources'; it can be construed that its provisions do not aptly capture the indicators of incorporating the environmental protection pillar.

\subsubsection{BITs and the Economic Development pillar}

The extent to which the three BITs have addressed the economic development pillar of sustainable development was analysed with specific reference to two principles namely: poverty eradication; and equity. Collectively, the two principles encourage cooperation for the eradication of poverty so as to raise living standards and for equity in terms of fair access to natural resources for prosperity and posterity. From table 2, it is evident that the preambles of the three BITs integrate, to a certain extent, the economic development pillar of sustainable development. In particular, the assessment found that the preambles of the three BITs seek to protect and promote investment on the assumption that this will increase the economic prosperity of the Kenyan state leading to economic development. This is because, the BITs objectify three items namely; (i) the creation of favourable conditions for investment; (ii) the encouragement and reciprocal protection of investment in a manner that will stimulate individual business initiatives and increase prosperity; and (iii) the intensification of economic relations. For instance, the preamble of the UK-Kenya BIT provides:

[The Contracting Parties desire] to create favourable conditions for greater investment by nationals and companies of one state in the territory of the other state...[r] ecognising that the encouragement and reciprocal protection under international agreement of such investment will be conducive to the simulation of individual business initiative and will increase prosperity of both States...emphasis added

Similarly, the preamble of the German-Kenyan BIT seeks to:

...create favourable conditions for investment by nationals and companies in the territory of the other state recognizing that the encouragement and contractual protection of such investments are apt to stimulate private business initiative and increase [economic] prosperity of both nations...emphasis

Related, the preamble of the Netherlands-Kenyan BITs provides:

The Government of the Kingdom of the Netherlands and the Government of the Republic of Kenya, Desiring to strengthen their traditional ties of friendship, to extend and intensify their economic relations and to encourage investments on the basis of equality to their mutual benefit...emphasis added

The foregoing objectives are in line with the assumption that foreign investment should be protected as a way of attracting and reaping sustainable developmental benefits. They also reinforce the fact that a country's prosperity and prosperity is pegged on an increase in investment inflow. Notably, even though the BITs refer to 'increasing 
prosperity', they neither make direct reference to the sustainable economic development nor do they create any obligations on the contracting nations to promote intergenerational and intra-generational equity and poverty eradication as principles underpinning the economic pillar of sustainable development. Nevertheless, the Netherlands-Kenya BIT seems to directly address the economic pillar.Specifically, Article 2 of the Netherlands-Kenya BIT makes direct reference to the economic pillar of sustainable development by seeking to:

... [foster] co-operation between the state contracting parties, companies, associations and other organizations...connected with their economic life and all nationals engaged in economic activities in order to develop their national resources...emphasis added

The said article indicates recognition of the place of other relevant actors when fostering co-operation in pursuit of economic activities, which could lead to the eradication of poverty because "resources" can be exploited to meet economic needs.

\subsubsection{BITs and the Social Development pillar}

The social development pillar is indicated by a guarantee of the right to access judicial organs and the participation of the public in development. From table 2 we deduce that none of the preambular and specific declarations of the three BITs explicitly integrate a commitment to the social pillar of sustainable development. However, the general exception clauses of the three BITs somehow attempt to advance the social pillar in the case of 'expropriation' for a public benefit. ${ }^{36}$ For instance, Article 5 of the UK-Kenya BIT allows expropriation for public purposes relating to the 'internal needs' of a state as follows:

Investments of nationals or companies or either Contracting Party shall not be nationalised, expropriated ... in the territory of the other Contracting Party except for a public purpose related to the internal needs of that Party on a non-discriminatory basis and against prompt, adequate and effective compensation...emphasis added Likewise, Article 4(2) of the German-Kenya BIT also allows expropriation for 'public benefit' upon payment of compensation as follows:

Investments of nationals or companies or either Contracting Party shall not be nationalised, expropriated ... in the territory of the other Contracting Party except for a public benefit and against compensation...emphasis added

Collectively, the foregoing provisions suggest that the 'public' as an inherent principle within the social pillar of sustainable development is addressed under the said BITs. As the articles provide, the investor protections inherent in the three BITs may pave way for measures amounting to expropriation in the interest of the public. ${ }^{37}$ Accordingly, one may deduce that the three BITs seek to secure the 'public' participation as an underlying principle of the social development pillar. However, drawing such a deduction would negate the truth. This is so because public participation under the social pillar of sustainable development envisages not only involvement of all interested parties in decision-making but also access to judicial organs. ${ }^{38}$ Further, the fact that the host states,

\footnotetext{
${ }^{36}$ By expropriation, we mean the takingby the government of tangible or intangible property owned by private persons by means of administrative or legislative action. See further Tecmed v Mexico, ICSID ARB(AF)/00/2,Award,29 May 2003 Para 113

37 The 'public interest', in most cases, refers to a pecuniary or some interest borne by a 'class of community' but virtue of which their legal rights are affected. The interest can be economic, social or environmental so long as it is borne by a community. As per LJ Campbell in Republic vs. Bedfordshire (24.L.J.Q.B.84).

${ }^{38}$ See Article 14 of the Netherlands-Kenya BIT, Article 1 of the German-Kenya BIT and Article 3 of the UK -Kenya BIT.
} 
which largely consist of developing countries, must pay compensation for any expropriatory measures may render securing public interest quite costly and thus avoidable.

From the foregoing assessment and as evident form Table 2, it is deducible that to a large extent the three Kenyan BITs has failed to explicitly integrate sustainable development. The Kenyan BITs have largely favored the rights and interests of investors in having their investment protected through minimum standards of treatment clauses that enable BITs fulfill their traditional role of protecting foreign investment. It is no surprise then that the said clauses formed the bulk of the substantive provisions of the BITs in comparison to explicit provisions on sustainable development as shown in the distribution table 3 below.

Table 3: Distribution ratio of substantive provisions on minimum standards of treatment clauses that protect foreign investment viz the provisions on sustainable development

\begin{tabular}{|l|l|l|l|l|}
\hline \hline BIT & $\begin{array}{l}\text { Total No } \\
\text { of Clauses }\end{array}$ & $\begin{array}{l}\text { No of clauses } \\
\text { explicitly } \\
\text { incorporating } \\
\text { sustainable } \\
\text { development }\end{array}$ & $\begin{array}{l}\text { No of clauses on } \\
\text { minimum } \\
\text { standards of } \\
\text { treatment clauses } \\
\text { protecting foreign } \\
\text { investment }\end{array}$ & $\begin{array}{l}\text { Content of remaining } \\
\text { clauses }\end{array}$ \\
\hline $\begin{array}{l}\text { German-Kenya } \\
\text { BIT }\end{array}$ & 13 & 0 & 6 & $\begin{array}{l}\text { Remaining clauses dealing } \\
\text { with procedural matters such } \\
\text { as definitions, mode of } \\
\text { settling disputes, territorial } \\
\text { application, entry into force, } \\
\text { etc. }\end{array}$ \\
\hline $\begin{array}{l}\text { Netherlands- } \\
\text { Kenya BIT }\end{array}$ & 18 & 0 & 5 & Same as above \\
\hline
\end{tabular}

Source: Author

Notably, even though Kenya has focused on measures that guarantee the minimum standards of protection to investors under BITs; in line with the assumption that by protecting foreign investment they shall reap the necessary finance for sustainable development, the revenue generated from FDI has been unpredictable. Indeed, from the 1970's to 2006 there was an increase in FDI inflows in Kenya which meant an increase in revenue generated from foreign capital that could finance sustainable development. However, from the year 2006, the FDI inflows have remained volatile and on a decline as illustrated below. In turn, this lends to the deduction that difficulties are prevalent in measuring and using FDI to plan development projects that will yield long-term sustainable benefits.

FDI Inflow in Kenya between 1970 -2006

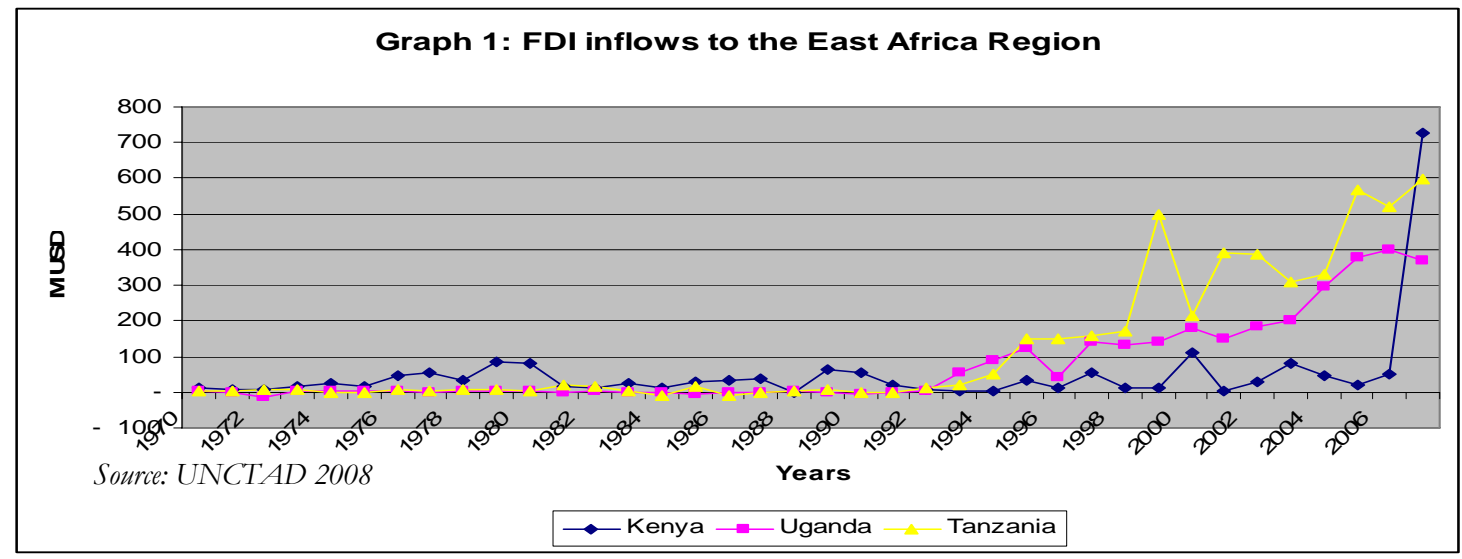




\section{Conclusion}

The assessment on how and to what extent the BITs can be tools for sustainable development, using the Kenyan BITs as illustrative examples, has showed that to a large extent, sustainable development remains a mirage. The lack of integration of the pillars and the principles of sustainable development warrants this assertion. The Kenyan BITs have largely favoured the rights and interests of investors in having their investment protected through minimum standards of treatment clauses that enable BITs fulfil their traditional role of protecting foreign investment. Although it can be said that the minimum standards are in line with the assumption that by protecting foreign investment, one can reap sustainable development benefits in the form of capital necessary to finance the same, such an assumption is not enough. As highlighted, revenue generated from foreign investment remains unpredictable. This in turn creates difficulties in using the said revenue when planning for long-term sustainable yields in development. Ultimately, States must rethink how the BITs can integrate sustainable developmental concerns whilst at the same time fulfilling their traditional role of promoting and protecting investment. The states must take deliberate steps recast BITs to ensure that the process of negotiation of BITs, the structure that emanates from the negotiation and the implementation of the BITs; explicitly seek to integrate sustainable development. This necessarily involves placing obligations on both state and non-state actors in realizing sustainable development.

\section{References}

Agenda 21: Programme of Action for Sustainable Development, Report of the UNCED 1992, vol. U.N. GAOR, 46 th Sess.

Agreement between the Government of the United Kingdom of Great Britain and Northern Ireland and the Government of the Republic of Kenya Available online at http://www.unctadxi.org/templates/DocSearch 779.aspx

Agreement for Economic Co-operation between the Government of the Kingdom of the Netherlands and the Government of the Republic of Kenya Available online at http://www.unctadxi.org/templates/DocSearch_779.aspx

Drexhage, J, J, \& Murphy, and D. (2010). Sustainable Development: From Brundtland to Rio 2012.Background Study prepared for consideration by the High Level Panel on Global Sustainability at its first meeting, 19 September 2010. New York: United Nations

Dubava, I. (2010). Reconciling International Investment Law and Sustainable Development: Necessity or Luxury? Society of International Economic Law \& University of Missouri Kansas City School of law. Study presented at the Second Biennial Conference held 8-10 July 2010 at the University of Barcelona.

Fabienne, F, \& Maher, M. (2O11).Foreign Direct Investment and Sustainable Development. OECD Journal Financial Market Trends. Paris: OECD

Gro H, Brundtland et al. (1987). Our Common Future: The Report of the World Commission on Environment and Development. Oxford: Oxford University Press

Hardwick, Bahadur \& Langmead. (1999). An Introduction to Modern Economics. (5 ${ }^{\text {th }}$ Eds). United Kingdom: Longman Publishers

Hirsch, M. (2011). Sources of International Investment Law. Jerusalem: International Law Forum of Hebrew University of Jerusalem Faculty of Law.

Howley, J. (2009). The Gabcikovo-Nagymaros Case: The Influence of the International Court of Justice on the Law of Sustainable Development. Queensland Law Student Review Volume 2 number 1.

International Federation for Human Rights. (2008). Economic Development or Human Rights: Assessing the Impact of Kenya's Trade and Investment Policies and Agreements on Human Rights. The Netherlands:International Federation for Human Rights\& Centre for Research on Multinational Corporations 
International Institute for Sustainable Development.(2012). Investment Treaties and Why they matter for Sustainable Development: Questions and Answers. Canada: International Institute for Sustainable Development.

International Law Association. (2004). First Report of the International Law Committee on International Law on Sustainable Development. International Law Association

International Law Association. 2002. New Delhi Declaration on the Principles of International Law Related to Sustainable Development. London: International Law Association

Kates, W, R.; Parris, M, Thomas \& Leiserowitz, A. Anthony. (2005). What is Sustainable Development? Goals, Indicators, Values, and Practise. Washington: United States.

Kennedy, K. (2003). A WTO Agreement on Investment: A Solution in search of a Problem? Journal of International Economic Law volume 24 no 1 at pg 155

Knottnerus, R \& Roos van Os. (2011). Dutch Bilateral Investment Treaties: A gateway to Treaty Shopping for Investment protection by multinational companies. Amsterdam: Stitching Onderzoek Multinationale Ondernemingen. See also Amarasinha op cit n 49

Leo, B. (2010). Where are the BITs? How US Bilateral Investment Treaties with Africa Can Promote Development. United States: Centre for Global Development

Ling Yoke, C. (2012). The Rio Declaration on Environment: An Assessment. Malaysia: Third World Network.

Markert, L. (2011). The Crucial Question of Future Investment Treaties: Balance Investors' Rights and Regulatory Interests of the Host State. In Brungenberg, $\mathrm{M}$ et al. (Eds). International Investment Law and EU Law. Berlin: Springer-Verlag Berlin Heidelberg

Mebratu, D. (1998). Sustainability and Sustainable Development: Historical and Conceptual Review. New York, NY: Elsevier Science Inc.

Muchlinski, P; Ortino, F \& Schreuer, C (Eds). (2011) The Oxford Handbook of International Investment Law. Oxford: Oxford University Press

Newcombe, A \& Luis, P. (2009). Law and Practice of Investment Treaties: Standards of Treatment. The Netherlands: Kluwer Law International.

Pritchard, R. (1996).Economic Development, Foreign Investment and the Law: Issues of Private Sector Involvement, Foreign Investment, and Rule of Law in a new Era. The Hague London and Boston: Kluwer Law International and International Bar Association.

Puvimanasinghe, S. (2007). Towards A Jurisprudence of Sustainable Development in South Asia: Litigation in the Public Interest. Leiden: Koninklijke Brill NV

Rio Declaration on Environment and Development 1992

Sauvant, K. (2012). The times they are a-changin'-again-in the relationships between governments and multinational enterprises: From control, to liberalization to rebalancing. Canada: Vale Columbia Center on Sustainable International Investment.

Segger, C, M., Gehring, M, W., \& Newcombe, A. (Eds.). (2011). Sustainable Development in World Investment Law. The Netherlands: Kluwer Law International

Subedi, S. (2008). International Investment Law: Reconciling Policy and Principle. Oregon: Hart Publishing

The Treaty between the Federal Republic of Germany and the Republic of Kenya Available online at http://www.unctadxi.org/templates/DocSearch 779.aspx

UNCTAD. (2003). World Investment Report 2003.FDI Policies for Development: National and International Perspectives. United Nations: New York and Geneva

UNCTAD. (2003). The Developmental Dimension of FDI: Policy and Rule-making Perspectives. Proceedings of the Expert Meeting held in Geneva. United Nations: Geneva and New York

UNCTAD. (2005). Rethinking Economic Development in Africa: Retbinking the Role of Foreign Direct Investment. United Nations: Geneva and New York

UNCTAD. (2008). International Investment Rule-making: Stocktaking, challenges and the way forward. Series on International Investment Policies for development. United Nations New York and Geneva.

UNCTAD. (2011). ILA Issues Note: Interpretation of ILAs: What states can do. United Nations: New York and Geneva.

United Nations Economic and Social Council. (2009). Human rights, trade and investment: Report of the High Commissioner for Human Rights. United Nations: New York

United Nations. (2003). Monterrey Consensus on Financing for Development: Report of the International Conference on Financing for Development 2002.

World Bank Annual publication Word Development Report 2003

World Development Movement \& Friends of the Earth. Investment and the WTO: Bursting the Myths. London: World Development Movement and Friends of the Earth. 